\title{
Cytomegalovirus infection in Gambian mothers and their babies
}

\author{
C Bello, H Whittle
}

\begin{abstract}
A 15 month longitudinal study of cytomegalovirus (CMV) infection in 178 Gambian mothers and their babies was undertaken. Twenty five $(14 \%)$ of the babies were congenitally infected despite the fact that $87 \%$ of their mothers were antibody positive to the virus. Two of the 25 congenitally infected infants had evidence of severe neurological damage; skin sepsis was also a prominent feature in congenitally infected infants. The other children soon became infected. At 6 months of age, $53 \%$ of the infants were shedding virus either in urine or saliva. By the age of 12 months $86 \%$ of the infants had serological evidence of $\mathrm{CMV}$ infection. Preliminary evidence suggests that sibling to sibling infection in crowded compounds might be a major route of transmission.
\end{abstract}

Cytomegalovirus is the commonest cause of congenital infection in man, and in the West it is known to be a cause of brain damage. ${ }^{1}$ Primary infection in pregnancy, which is common in those of high socioeconomic status, results in congenital infection in half the babies born to mothers in these classes. ${ }^{2}$ Between $2-7 \%$ of these children will sustain neurological damage. ${ }^{34}$ Reactivation of infection occurs in seropositive mothers who are usually of lower socioeconomic status who have been infected during childhood. ${ }^{2}$ Six per cent of infants born to seropositive mothers with active recurrent infection become congenitally infected but neurological damage in their children is rare. ${ }^{5}$ Most infections, however, occur in childhood and are asymptomatic. ${ }^{6}$ Thereafter the virus remains latent but may subsequently cause severe recurrent infection if an individual is immunosuppressed which happens in transplant recipients ${ }^{7}$ or in those with AIDS. ${ }^{8}$ CMV has been isolated from saliva, ${ }^{9}$ breast milk, ${ }^{10}$ blood, urine, semen and cervical secretions. The natural routes of infection still remain to be clearly defined and are likely to vary with socioeconomic status and sexual behaviour.

Sexual transmission is probably important in upper class non-immune heterosexuals and homosexuals. ${ }^{11}$ Breast milk is probably a major route of transmission in poor communities. ${ }^{10}$ The role of saliva or urine in transmission of infection from older sibling to younger sibling is still to be defined.

Little is known about the importance of the epidemiology of CMV in Africa. Serological evidence points to frequent and early infection in childhood, ${ }^{12} 13$ but the incidence of congenital infection and its long term effects on the nervous and immune system in a tropical environment are unknown. The only study in West Africa which involved isolation of the virus was undertaken in Abidjan, the Ivory Coast, ${ }^{14}$ where $1.4 \%$ of babies born in hospital were congenitally infected. This figure may have been artifically low because difficulties arose during the storage and transportation of specimens to Europe for viral isolation. Routes of infection in Africa have not been charted. In particular, the relative importance of mothers and older siblings in transmission needs to be elucidated.

In an attempt to fill these gaps in our knowledge we undertook a community based longitudinal study of $\mathrm{CMV}$ in mothers and their babies in The Gambia, West Africa.

\section{Methods}

One hundred and seventy eight pregnant women (mean (SD) age $25.60(5.94)$ years) and their 184 babies, including six sets of twins, were recruited from urban (Banjul and Brikama) and rural (Brefet and Sibanor) Gambia. The women were enrolled when 36-40 weeks pregnant and studied for periods ranging from nine to 15 months after the birth of their baby. A cervical swab and finger-prick blood sample for CMV antibody were taken once from 178 mothers at the time of enrolment while urine, saliva, and breast milk for CMV culture were collected at three monthly intervals. One hundred and eighty four urine, 184 saliva, 184 cord or finger-prick blood samples were collected from the babies within three weeks of birth (mean (SD) $7.5(5 \cdot 1)$ days), and at three monthly intervals thereafter. Only 178 blood samples were processed; some specimens were either spilt or became contaminated. Congenital infection was assumed if either the babies' saliva or urine contained virus in the first samples taken within the first three weeks of birth.

IgG antibody was measured by immunofluorescence. Specimens for culture were placed in ice-cold transport medium, kept cool, and on arrival at the laboratory either inoculated on to MRC-5 Fibroblast or kept at $-70^{\circ} \mathrm{C}$ until processed.

Cells were examined for typical cytopathic effects for a minimum of three weeks before being discarded as negative. Isolates were identified as positive for cytomegalovirus by their 
cytopathic effects, by immunofluorescence of. infected cells using CMV specific fluorescein conjugated anti-serum (Behring Institute, Germany) and by neutralisation using AD 169 specific antiserum prepared in guinea pigs in our laboratory. A sample of seven of our isolates, positive by the above criteria, were independently confirmed as CMV positive at $\mathrm{St}$ George's Hospital Medical School, London (Courtesy of Dr JC Booth).

Morbidity data were collected (CB) from children seen at three monthly intervals and whenever their mothers thought they were sick. One hundred and seventy eight, 175, 170, 161,142 and 69 mothers, respectively, were seen at enrolment, then at three, six, nine, 12 and 15 months' follow up. Twelve of the mothers dropped out of the study because their babies died before the study ended. The study was approved by the MRC/Gambia government ethical committee.

\section{Results}

No consistent significant differences were noted in the prevalence of CMV antibody or viral excretion between rural and urban subjects. Therefore data derived from these two sources were pooled. Most mothers were antibody positive to CMV; antibody was detected in 147/ $168(87.5 \%)$ of sera at the time of enrolment. The prevalence of mothers excreting CMV according to specimen and time after birth of their babies is shown in table 1. A low prevalence of intermittent excretion of virus was found. Over a year only three of 139 mothers were found to have excreted virus in either saliva or breast milk on more than one occasion. The mean (SD) titre of virus in saliva, urine, and breast milk was $3.2(1.9) ; 3.8(2 \cdot 8)$; and $1.4(8 \cdot 6) \log _{10} \mathrm{TCID}_{50} / \mathrm{ml}$, respectively.

The prevalence of CMV antibody and of viral excretion was very high in the babies. The prevalence of antibody dropped to $68-70 \%$ during the first six months of life, but by 12 months of age it had risen to $86.4 \%$, a figure similar to that found in the mothers. Fourteen per cent $(25 / 178)$ of the babies were probably congenitally infected, shedding virus in either saliva $(12 / 25)$ or urine $(16 / 25)$ in the first three weeks of life. Thereafter the prevalence of viral excretion rose rapidly to a peak of $53 \%$ at 6 months. By then, $40 \%$ of the infants shed virus in urine and $37 \%$ shed virus in saliva. Excretion of virus was much less intermittent than in the mothers: over a year 94 of 150 infants $(62 \%)$ shed virus in either saliva or urine on more than one occasion. Viral titres in both urine and saliva were not significantly higher than those found in the mothers' specimens. The mean CMV titre in saliva was $3.7(1.9) \log _{10}$ $\mathrm{TCID}_{50} / \mathrm{ml}$ and in urine $3.4(1.6) \log _{10}$ $\mathrm{TCID}_{50} / \mathrm{ml}$.

\section{CONGENITAL INFECTION}

The mean (SD) age of the 25 mothers of congenitally infected infants was $25 \cdot 2(6 \cdot 3)$ years and their mean parity was $2 \cdot 3(2 \cdot 3)$ births. Six of the $25(24 \%)$ congenitally infected infants were firstborn. The mean age of the 153 other mothers was $25 \cdot 7(6 \cdot 8)$, their mean parity was $2.9(2 \cdot 3)$. Nineteen of $159(11 \cdot 1 \%)$ of their infants were firstborn. The differences were not significant.

Congenitally infected infants tended to excrete virus more consistently than infants who acquired the infection later, 10 of $20(50 \%)$ of the congenitally infected infants shed virus in either urine or saliva on at least three consecutive occasions. Comparable figures for infants infected at or after birth were 35 out of $88(39 \cdot 7 \%)$. This difference, however, was not significant.

Mothers of congenitally infected infants were no more likely to be excreting the virus at birth than the mothers of their counterparts. Five of the $25(20 \%)$ mothers of congenitally infected infants excreted CMV in cervical secretions, urine, saliva, or breast milk compared with 27 of the $153(17.6 \%)$ other mothers. Weight, length, and head circumference of infants with congenital infection and those of infants infected after birth were measured and compared over the first 12 months. Both comparisons of these measurements between the sexes and children of the same sex were not significant. All except two of the congenitally infected infants were normal at birth. These two showed evidence of motor neurone damage. Both failed to reach normal growth milestones at the expected time, had some degree of hearing loss, and failed to thrive. One of these infants had cortical blindness and the other died suddently at home at one year of age. Syphilis, toxoplasma and rubella IgM antibodies were absent in these two infants and their mothers. None of the infants infected after birth had motor neurone damage.

Table 2 shows some of the illnesses the babies sustained during the study period and compares the incidence of diseases in congenitally and non-congenitally infected infants. Skin sepsis or pyoderma was significantly more common in congenitally infected infants than in controls $\left(\chi^{2}=13.8, \mathrm{p}<0.001\right)$. Pneumonia or lower respiratory tract infection and diarrhoea with vomiting were equally common in the two groups.

Table 1 CMV excretion (No/\%) by mothers according to specimen and time after birth

\begin{tabular}{|c|c|c|c|c|c|c|c|c|c|c|c|}
\hline \multirow[b]{2}{*}{ Specimen } & \multicolumn{11}{|c|}{ Time after birth (months) } \\
\hline & 0 & & 3 & & 6 & & 9 & & 12 & & 15 \\
\hline $\begin{array}{l}\text { Urine } \\
\text { Saliva } \\
\text { Breast milk } \\
\text { Any of the above positive } \\
\text { Cervical swab } \\
\text { (at enrolment only) }\end{array}$ & $\begin{array}{r}9 / 178 \\
11 / 178 \\
7 / 160 \\
27 / 157 \\
12 / 178\end{array}$ & $\begin{array}{l}(5 \cdot 1) \\
(6 \cdot 2) \\
(4 \cdot 4) \\
(17 \cdot 2) \\
(6 \cdot 7)\end{array}$ & $\begin{array}{r}8 / 156 \\
3 / 156 \\
4 / 151 \\
14 / 151\end{array}$ & $\begin{array}{l}(5 \cdot 1) \\
(1 \cdot 9) \\
(2 \cdot 6) \\
(9 \cdot 3)\end{array}$ & $\begin{array}{r}6 / 148 \\
8 / 147 \\
3 / 123 \\
17 / 123\end{array}$ & $\begin{array}{l}(4 \cdot 1) \\
(5 \cdot 4) \\
(2 \cdot 4) \\
(13 \cdot 8)\end{array}$ & $\begin{array}{l}5 / 149 \\
4 / 150 \\
1 / 124 \\
9 / 117\end{array}$ & $\begin{array}{l}(3.4) \\
(2 \cdot 7) \\
(0.8) \\
(7 \cdot 7)\end{array}$ & $\begin{array}{r}4 / 143 \\
7 / 144 \\
2 / 127 \\
13 / 126\end{array}$ & $\begin{array}{l}(2 \cdot 8) \\
(4 \cdot 9) \\
(1 \cdot 6) \\
(10 \cdot 3)\end{array}$ & $\begin{array}{ll}0 / 66 & (0 \cdot 0) \\
1 / 63 & (1 \cdot 6) \\
4 / 56 & (7 \cdot 1) \\
5 / 54 & (9 \cdot 3)\end{array}$ \\
\hline
\end{tabular}


Table 2 Clinical features of congenitally infected and non-congenitally infected infants

\begin{tabular}{lrr}
\hline Clinical features & $\begin{array}{l}\text { Congenitally } \\
\text { infected infants }\end{array}$ & \multicolumn{2}{c}{$\begin{array}{l}\text { Non-congenitally } \\
\text { infected infants }\end{array}$} \\
\hline Motor neurone damage & $2 / 25(8 \cdot 0 \%)$ & $0 / 153(0 \cdot 0 \%)$ \\
Skin sepsis & $10 / 25(40 \cdot 0 \%)$ & $15 / 153(9 \cdot 8 \%)$ \\
Pneumonia & $7 / 25(28 \cdot 0 \%)$ & $35 / 153(22 \cdot 9 \%)$ \\
Diarrhoea/diarrhoea and vomiting & $5 / 25(20 \cdot 0 \%)$ & $31 / 153(20 \cdot 3 \%)$ \\
\hline
\end{tabular}

Table 3 CMV excretion in mothers and siblings of 22 infants at six months of age

\begin{tabular}{lll}
\hline & \multicolumn{2}{c}{$C M V$} \\
\cline { 2 - 3 } & Positive & Negative \\
\hline Siblings & 15 & $26^{\star}$ \\
Mothers & 2 & 20 \\
\hline
\end{tabular}

*Twenty two infants had 41 siblings who were sampled.

\section{SOURCES OF INFECTION}

To test the possibility that CMV infection might also be transmitted from older siblings to infants, we cultured urine and saliva from 41 siblings aged 10 years or younger of 22 randomly selected infants in the study. At the same time their mothers' urine, saliva, and breast milk was cultured. Table 3 shows that siblings were more likely to excrete virus than the mother of the infants $\left(\chi^{2}=4 \cdot 2, \mathrm{p}<0.05\right)$.

\section{Discussion}

Our longitudinal study of CMV infection in mothers and babies substantiates previous sereological evidence from West Africa which showed that most mothers were antibody positive and that their children were infected with CMV early in life. ${ }^{13} \mathrm{~A}$ major surprise has been the high number of congenital infections we found in the Gambia. With the exception of one case, all occurred in antibody positive mothers. The only comparable reported figures are an incidence of $9.7 \%$ in a seropositive population ${ }^{15}$ and an incidence of $10 \%$ following primary infection. ${ }^{16}$

In the only other study in West Africa in which viral isolation was attempted, Schoffer et al were able to culture CMV virus from the urine of 28 of $2032(1.4 \%)$ new born babies in a hospital in Abidjan, Ivory Coast. ${ }^{14}$ This figure may be artificially low because the urine had to be transported to Europe before culture. Our study differed from theirs in a variety of ways: the study was community based; both saliva and urine were sampled during the first three weeks; and specimens were processed immediately or after storage at $-70^{\circ} \mathrm{C}$.

The mode of congenital infection was unclear because mothers of infected infants were no more likely to be excreting virus from cervix or other sites at the time of birth than the mothers of the other infants. We were unable to assess the role that immunosuppressive infections such as malaria may have been influential during pregnancy because only one set of samples and one set of clinical data were obtained from the mother just before birth.

In The Gambia, as well as in many African countries, mothers introduced their saliva into their babies' mouth pretty early. For example, boiled water is given to a newborn baby to drink from birth; and it is customary that the mother measures the temperature of the water, which is often put in a teaspoon, in her own mouth before giving it to the baby. CMV could also be introduced into the baby's mouth by the mother when she and other close relatives kiss the baby. In view of these practices, therefore, it may be unwise to rely on saliva for CMV isolation in West Africa. If reliance is on urine alone, then our incidence of congenital CMV infection in this study becomes $9 \%(16 / 178)$.

The clinical consequences of congenital infection in this environment seem to be of some importance; two of the $25(8 \%)$ of the babies had severe motor neurone damage which was likely to be due to CMV because serological evidence of other common congenital causes of neurological damage was absent.

This prevalence is similar to that found in congenitally infected infants born to mothers with primary CMV infection in pregnancy. Skin sepsis was surprisingly common in the congenitally infected infants, and if left untreated, may have resulted in increased morbidity and mortality. Growth was little affected for although congenitally infected males tended to grow less well than their postnatally infected counterparts, this feature never assumed any clinical importance.

Infants, if not congenitally infected, soon become silently infected during the first months of life when the limited immunity conferred by maternal antibody started to wane. CMV, like Epstein Barr and herpes simplex viruses, thereafter remains latent in various cells of the body.

In our environment it is as well to remember that by the time the major immunosuppressive infections of childhood such as malaria, ${ }^{17}$ or measles strike, ${ }^{18}$ the child already harbours herpes viruses. The part that reactivated CMV plays in infection of the lung in immunosuppressed children needs to be defined. Certainly herpes simplex virus can be reactivated after measles to cause life threatening infection of the eye, mouth, and lung. ${ }^{19}$ Reactivation of Epstein Barr virus during malaria may have a role in the genesis of Burkitt's lymphoma. ${ }^{20}$ The mode of transmission of CMV in our environment is unknown. Previous work in the West suggests that mothers are the main source of infection to infants and that a major route of infection may be through breast milk which often contains the virus in low titre ${ }^{10}$ Child to child transmission, however, has been reported in a day care centre ${ }^{21}$ and in a kibbutz. ${ }^{22} \mathrm{We}$ think this route may be important in our environment for older siblings are in very close contact with their younger siblings, often sleeping two or three to a bed. The chances of cross infection with either saliva or urine in such a situation are high. We found that the mothers have a relatively low prevalence of CMV excretion and that they only intermittently excreted the virus.

In contrast, older siblings and unrelated children had a high prevalence of CMV excretion. Unfortunately, we have no longitudinal data on prevalence of excretion or titre of virus 
excreted so the supposition that older siblings are important transmitters of infection remains to be proved.

We thank Mr Seedy Rahman and Mr Keith Williams for their expert technical assistance and $\mathrm{Mr}$ Lamin Jammeh, $M$ Musukebba Bojang, and Miss Wally Secka for help in the field. We gratefully acknowledge the support of Dr Greenwood, director of the MRC Laboratory, The Gambia. Our gratitude also goes to Mrs Celina Dasat who painstakingly typed and retyped the scripts, and to Mrs S Tulloch who helped with the analysis of the data.

1 Elek SD, Stern H. Development of vaccine against mental retardation caused by cytomegalovirus infection in utero. Lancet 1974;i:1-5.

2 Stagno S, Pass RF, Dworsky ME, et al. Congenita cytomegalovirus infection. N Engl J Med 1982;306:945-9.

3 Peckham CS, Chin KS, Coleman JC, Henderson K, Hurley R, Preece PM. Cytomegalovirus infection in pregnancy: 1983;1:1352-5.

4 Stern H, Elek SD, Booth JC, Fleck DG. Microbial causes of mental retardation. The role of prenatal infections with cytomegalovirus, rubella virus and toxoplasma. Lancet 1969;ii:443-8.

1969;ii:443-8.

Medearis DN. CMV immunity: Imperfect but protective. $N$ Engl J Med 1982;306:985-6.

6 Weller TH. The cytomegaloviruses: ubiquitous agents with protean clinical manifestations. $N$ Engl J Med 1971;285 267-73.

7 Rubin RH, Cosimi AB, Tolkoff-Rupin ME, Russel PS Hirsch MS. Infectious disease syndromes attributable to cytomegalovirus and their significance among renal transplant patients. Transplant 1977;24:458-64.
8 Centres for Disease Control. Epidemiologic aspects of current outbreak of Kaposis sarcoma and opportunistic infections. N Engl J Med 1982;306:248-52.

9 Weller TH. Cytomegaloviruses: the difficult years. J Infect Dis 1970;122:532-9.

10 Stagno S, Reynolds DM, Pass RF, Alford CA. Breast milk and the risk of cytomegalovirus infection. $N$ Engl J Med 1980;302:1073-6.

11 Drew LW, Mintz RC, Sands M, Ketterrer B. Prevalence of cytomegalovirus infection in homosexual men. J Infect Dis 1981;143:188-92.

$12 \mathrm{Krech}$ U. Complement-fixing antibodies agains cytomegalovirus in different parts of the world. Bull World Health Org 1973;49:103-6.

13 Krech U, Tobin JA. Collaborative study of cytomegalovirus antibodies in mothers and young children in 19 countries. Bull World Health Org 1981;54:605-10.

14 Schopfer K, Lauber E, Krech U. Congenital cytomegalovirus infection in new born infants of mothers infected vefore pregnancy. Arch Dis Child 1978;53:536-69.

15 Nankervis GA, Kumar HL. Diseases produced by cytomegaloviruses. Med Clin North Am 1978;62:1021-33.

16 Medearis DN. Human cytomegalovirus immunization Medearis DN. Human cytomegalovirus imn
prospects. N Engl J Med 1977;296:1280-90.

17 Greenwood BM, Bradley-Moore AM, Palit A, Bryceson ADM. Immunosuppression in children with malaria. Lancet 1972;i:169-72.

18 Whittle HC, Bradley-Moore A, Fleming A, Greenwood $B M$. Effects of measles on the immune response of Nigerian children. Arch Dis Child 1973;48:753-6.

19 Whittle HC, Sandford Smith J, Kogbe OI, Drosetor J, Duggan M. Severe ulcerative herpes of mouth and eye following measles. Trans Roy Soc Trop Med Hyg 1979;73:66-9.

20 Whittle HC Brown J, Marsh $\mathrm{K}$, et al. $\mathrm{T}$ Cell control of Epstein-Barr virus-infected B cells is lost during falciparum malaria. Nature 1984;312:449-50.

21 Pass RF, August AM, Dworsky $M$, Reynolds DW. Cytomegalovirus infection in a day care center. $N$ Engl $J$ Med 1982;307:477-9.

22 Moraq A, Zilber J, Harva E. Early acquisition of cytomegalovirus antibodies in communal settlemen (Kibbutzem) in Israel. Am J Epidemiol 1984;119:238-43. 